\title{
HUMANIZATION, RATIONALIZATION OR SUBJECTIFICATION OF WORK? EMPLOYEE-ORIENTED FLEXIBILITY BETWEEN I-DEALS AND IDEOLOGY IN THE NEOLIBERAL ERA ${ }^{1}$
}

Severin HORNUNG ${ }^{2}$

Thomas HÖGE ${ }^{3}$

\author{
Received Date (Başvuru Tarihi): 05/10/2019 \\ Accepted Date (Kabul Tarihi): 30/11/2019 \\ Published Date (Yayın Tarihi): 25/12/2019
}

\section{ABSTRACT}

This article discusses promises and pitfalls of employee-oriented workplace flexibility. The concept of employee-oriented flexibility applies to broad-based programs and individualized approaches. Here, the focus is on idiosyncratic deals (i-deals), individually negotiated work arrangements. Reviewing the literature, theory on characteristics, prerequisites, and limits of mutually beneficial flexibility is developed in the context of the neoliberal reconfiguration of work, employment, and societies. The dialectic construction of antagonistic types is used to differentiate employee-oriented $i$-deals from ideological counter-applications of economic rationalization. The latter reflect neoliberal ideologies of individualism, competition, and instrumentality, the former humanistic ideals of individuation, solidarity, and emancipation. Symptomatic for psychological governance through "subjectification", self-enacted forms of rationalization threaten to undermine humanization prospects. Divisive management practices, politically motivated rhetoric, and inherently distorted theorizing are based on confounding "hidden modes" of workplace flexibility, the deconstruction of which advances scholarship.

Keywords: Workplace Flexibility, Idiosyncratic Deals, Humanistic Management, Neoliberal Ideology, Subjectification, Governmentality

JEL Codes: B5, D6, J5, M1, Z13

\section{IŞ̧i İNSANILEŞTİRMEK Mİ, RASYONALLEŞTIRMEK Mİ YOKSA}

\section{ÖZNELLEŞTIRMEK Mİ? İDIYOSINKKRATIK ANLAŞMALAR VE NEOLİBERAL DÖNEMDE İDEOLOJI ARASINDA ÇALIŞAN ODAKLI ESNEKLIKK}

$\ddot{O} Z$

Bu makalede, çalışan odaklı işyeri esnekliğinin vaatleri ve güçlükleri tartışılmaktadır. Çalışan odaklı esneklik kavramı geniş tabanlı programlar ve bireysel yaklaşımlar için uygundur. Bu çalışmada idiyosinkratik anlaşmalar (i-anlaşmalar) ve bireysel olarak müzakere edilmiş çalışma düzenlemelerine odaklanılmıştır. Literatür

\footnotetext{
${ }^{1}$ Earlier versions of this paper were presented by the first author at the 11th International Critical Management Studies Conference, held at the Open University, Milton Keynes, in June 2019; the II. BOR Business \& Organization Research Conference, held at Yasar University, Izmir, Turkey, in September 2019; and in the New School of Management Research Seminars at the University of Bristol in October 2019. The authors wish to thank the participants at all these events for constructive discussions, helpful comments, and collegial encouragement.

${ }^{2}$ Priv.-Doz. Dr., University of Innsbruck, Austria, Institute of Psychology, Applied Psychology Division, severin.hornung@uibk.ac.at https://orcid.org/0000-0001-5035-3558

${ }^{3}$ Priv.-Doz. Dr., University of Innsbruck, Austria, Institute of Psychology, Applied Psychology Division, thomas.hoege@uibk.ac.at https://orcid.org/0000-0003-3061-6271
} 
incelendiğinde, karakteristik özellikler, önkoşullar ve karşılıklı yarar sağlayan esnekliğin sınırları teorisi; iş, istihdam ve toplumların neoliberal yeniden yapılandırılması bağlamında geliştirilmiştir. Antagonistik türlerin diyalektik yapısı, çalışan odaklı idiyosinkratik anlaşmaları, ekonomik rasyonalizasyonun ideolojik karşı uygulamalarından ayırmak için kullanılmıştır. İkincisi bireyselliğin, rekabetin ve aracılı̆̆ın neoliberal ideolojilerini, bireyselleşme, dayanı̧̧ma ve özgürleşmenin eski hümanist ideallerini yansitıyor. "Öznelleştirme”" yoluyla yapılan psikolojik yönetimin belirtisi, kendiliğinden yasallaştırılan rasyonalizasyon biçimlerinin insanileşme beklentilerini yıkmakla tehdit etmesidir. Bölücü yönetim uygulamaları, politik motive edici söylem ve doğal olarak bozulmuş teorileştirme, işyeri esnekliğinin “gizli modlarını” karıştırmaya dayanmaktadır.

Anahtar Kelimeler: İşyeri Esnekliği, İdiyosinkratik Anlaşmalar, İnsancıl Yönetim, Neoliberal İdeoloji, Öznelleştirme, Yönetimsellik

JEL Kodlart: B5, D6, J5, M1, Z13

\section{RESEARCH ON WORKPLACE FLEXIBILITY}

The paradigm of flexibility, broadly described by increased heterogeneity, variability, and accelerated dynamics in organizational structures and processes, has dramatically changed the nature of work and employment in economically developed-so-called postindustrialsocieties (e.g., Brozovic, 2018; Smith \& Besharov, 2019). Manifestations of flexibility at the workplace level refer to employment and work practices, i.e., the structures and processes for the management of human resources, in terms of labor input and its transformation into profitable performance (e.g., Kalleberg, 2003). Despite a burgeoning amount of research, the multifaceted implications of workplace flexibility for individuals, organizations and society are complex and not well understood. Researchers have expressed this ambiguity with terms such as the "Janus Face", the "double-edged sword", the paradox, dialectics, or the "Pandora's Box" of flexibility (e.g., Cañibano, 2019; Gouliquer, 2000; Putnam, Myers, \& Gailliard, 2014). What these labels allude to are inherent tensions between positive and negative implications of flexibility in work and employment practices (e.g., Höge \& Hornung, 2015; Kalleberg, 2003, 2011; Kashefi, 2009). On the one hand, employees in flexible organizations are frequently confronted with various forms of heightened uncertainty (i.e., job insecurity, temporary and conditional employment and other forms of precariousness), work intensification (i.e., time pressure and escalating performance requirements) and extensification (i.e., extended and unpredictable work hours, permanent availability, and erosion of the private sphere; e.g., Burchell, Ladipo, \& Wilkinson, 2002; Kubicek \& Korunka, 2017). On the other hand, flexibility also holds the promise of a new quality of work, based on increased opportunities for personal and professional development, learning, and growth (i.e., challenging and frequently changing work tasks) as well as self-determination and autonomy (freedom to work anytime and anywhere). Here, this conundrum is referred to as the dialectics of flexibility between economic 
rationalization and humanization of work (Hornung \& Höge, 2019). The underlying rift partly stems from the heterogeneity and complexity of the manifestations, interpretations, and conceptualizations of flexibility — and the broad range of implications for organizations, different groups of individuals, and societies. However, the complexity of the topic does not fully explain the ambiguity and confusion surrounding the flexibility discourse. Rather, insights into the nature and consequences of workplace flexibility are ideologically obscured by economic interests instrumentalizing flexibility to advance labor political agendas of societal elites, such as managers, shareholders, and investors (e.g., Archibald, 2009; Gouliquer, 2000). Only recently, some attempts have been made to make these influences on work and organizational practices and scholarship more explicit by drawing on the political literature on neoliberal ideology as a socially and intellectually corrosive force in postindustrial societies, proliferating anti-humanistic logics of individualism, competition, and instrumentality (Bal \& Dóci, 2018; Hornung \& Höge, 2019). Notably, Bal and Dóci (2018) have initiated an important and lively debate on the role of neoliberal ideology in the field of work and organizational psychology - a discourse, the present article seeks to contribute to.

Predating this relatively novel debate, the concept of employee-oriented flexibility has been introduced to get a clearer picture and a more differentiated view of the broader phenomenon of workplace flexibility. The idea of employee-oriented flexibility stands in the tradition of movements aimed at the humanization of work (e.g., Kissler \& Sattel, 1982). It is explicitly distinct from employer perspectives emphasizing economic rationalization that is, increasing organizational efficiency and effectiveness under conditions of escalating environmental dynamics (e.g., Bromley, 1990; Rinehart, 1986). Instead, employee-oriented flexibility has been advocated as an alternative "high road" strategy, superior to conventional, bureaucratic, cost-oriented, and standardized modes of human resource (HR) management. It promises organizations competitive advantages in attracting, retaining, motivating, and developing increasingly diverse and proactive workforces by supporting employees in customizing their jobs to better suit their personal and professional needs, interests, and goals. The concept of employee-oriented flexibility is rather comprehensive and applicable to both formalized organizational practices, policies, programs, and interventions, as well as informal, individualized, and behavior-based approaches. The focus here is on the latter, specifically, the proactive construct of idiosyncratic deals (i-deals), which has emerged as a "hot topic" in contemporary organizational research (e.g., Caliskan \& Torun, 2019) with particular relevance for the concept of employee-oriented flexibility (Hornung, Glaser, \& Rousseau, 2018). I-deals 
are defined as individually negotiated work and employment conditions, based on voluntary and mutually beneficial non-standard terms, agreed upon between employees and their employers - typically represented by direct supervisors, HR or higher-level managers. In theory, functional and fair i-deals are part of the human side of the organization, distinct from dysfunctional favoritism and preferential treatment, and even more so from divisive employment politics and managerial labor utilization strategies (Rousseau, Ho, \& Greenberg, 2006). However, a critical reading of the literature suggests that the boundaries between the optimistic "ideal-type of i-deals", as a form of humanistic management to increase employeeoriented flexibility and their abusive misuse as an anti-type in the context of economic rationalization strategies are blurry (e.g., Bal \& Hornung, 2019; Hornung, 2018), necessitating more critical theorizing and empirical research on the conditions and characteristics of their positive and negative applications, transcending the confines of management rhetoric and motivated social accounts.

This article aims to provide a basis for such a critical research effort by integrating the literature on i-deals with the current debate on neoliberal ideology in work and organizational psychology (Bal \& Dóci, 2018). The theoretical ideal-type of i-deals as a form of employeeoriented flexibility is compared to and contrasted with the conceptual antipode of the individualization of work and employment as a broader labor political power strategy serving economic rationalization agendas. Individualized work arrangement serving the latter purpose can be identified by the extent to which they embody, proliferate, or advance neoliberal ideologies of individualism, competition, and instrumentality. In contrast, genuine (ideal-type) i-deals aim at realizing humanistic ideals of individuation, solidarity, and emancipation. Further, attention is called to processes of "subjectification", interpreted as a form of "negative dialectics" between these antagonistic types (Bal \& Hornung, 2019). Associated with advanced manifestations of psychological governance, subjectification refers to new patterns of selfdirected work intensification and extensification - as introjected and self-enacted forms of efficiency-oriented rationalization potentially undermining positive outcomes for employees (e.g., Höge, 2011; Höge \& Hornung, 2015; Hornung, Höge, Glaser, \& Weigl, 2016). This article advances organizational scholarship by analyzing, disentangling, and deconstructing different modes or agendas of workplace flexibility, the confounding of which underlies and reinforces politically motivated rhetoric, ideologically distorted theorizing, and divisive management practices. New avenues for critical theorizing and empirical research on flexibility and individualization at work in the neoliberal era from a dialectic and critical humanist perspective are proposed and preliminarily explored. 


\section{EMPLOYEE AND EMPLOYER PERSPECTIVES}

Employee-oriented (worker or individual) flexibility can be differentiated from employer (managerial or organizational) flexibility, depending on who actually controls the variabilities (flexibility potentials) in HR practices. Conventionally, organizational flexibility refers to institutional (i.e., managerial) control or power to execute short-term changes in the employed human resources and management systems to improve the alignment of supplied capacities and capabilities with changing and limitedly predictable requirements of dynamic environments, typically factor (input) and product (output) markets (Brozovic, 2018; Smith \& Besharov, 2019; Volberda, 1996). From an organizational perspective, labor flexibility is a multifaceted concept, including financial (compensation systems and labor costs), numerical (number of employees and contracted hours), temporal-spatial (work scheduling and location of work), and functional (work tasks and assignments) parameters of the employed workforce and HR system (e.g., Gouliquer, 2000; Kalleberg, 2003). Defined as a conceptual antipode, employee-oriented flexibility refers to the actual control individuals possess to vary, adjust, or modify their work and employment conditions to better fit personal needs, preferences, values, and goals (Hornung, 2018; Hornung \& Höge, 2019). Mirroring the institutional perspective, employee-oriented flexibility encompasses the ability to exercise influence over aspects of payment, number of hours employed, work scheduling, work location, and essential job duties. The perspective of employee-oriented flexibility, however, focuses explicitly on the circumstances under which non-standard, personalized work arrangements are genuinely-not merely in theory or rhetoric - chosen voluntarily and are truly advantageous for employees. Thus, an important additional precondition for employee-oriented practices is that their use does not incur or threaten any disproportionate losses, disadvantages or risks to the respective individuals, an issue that is particularly relevant in light of widespread evidence for the discrimination of employees with reduced or nonstandard work hours (e.g., Munsch, 2016; Pedaci, 2010; Kauhanen \& Nätti, 2015). The notion of employee-oriented flexibility is mindful of the frequently overlooked, downplayed, or ideologically obscured fact of diverging employee and employer flexibility interests, raising tensions with the promise of a "new quality of work" in contemporary organizations (e.g., Allan, O’Donell, \& Peetz, 1999; Archibald, 2009; Kubicek \& Korunka, 2017). Yet, comparing and contrasting employer- and employee-oriented conceptualizations of flexibility also reflects the optimistic assumptions that organizational design can take on more or less coercive or enabling forms, that HR management systems can, at least under certain preconditions, be oriented towards serving the common good of both 
employees and employers, that there exists a "high-road" in employment relations, or - in other words - that alternative forms of work organization and humanistic management promoting employee health, personality, and moral development are, in fact, conceivable, attainable, and practicable (e.g., Adler \& Borys, 1996; Chiva, 2014; Osterman, 2018; Pircher Verdorfer \& Weber, 2016; Weber, Unterrainer, \& Höge, 2019; Weber, Unterrainer, \& Schmid, 2009). In addition to systematically differentiating between employee and employer perspectives, some important distinctions need to be made with regard to the content dimensions of workplace flexibility as well as the processes by which the associated variabilities come about through bottom-up and top-down processes. A preliminary overview of some of the central concepts and distinctions used in this contribution is offered in Table 1. This table foreshadows both the content and structure of the following elaborations regarding different forms of workplace flexibility and antagonistic types of individually negotiated work and employment arrangements. Displayed are inherent tensions between employee-oriented projects aimed at the humanization of work versus economic rationalization agendas targeting "improvements" in organizational efficiency and financial performance. Associated fault lines, tensions, and conflicts are discussed in more detail in the following sections. 
Table 1. Overview of Theoretical Concepts, Descriptions, and Distinctions

\begin{tabular}{|c|c|c|}
\hline $\begin{array}{l}\text { Employee / Individual } \\
\text { Flexibility }\end{array}$ & Workplace Flexibility & $\begin{array}{c}\text { Employer / Organizational } \\
\text { Flexibility }\end{array}$ \\
\hline $\begin{array}{l}\text { Employee Autonomy: } \\
\text { Control over variabilities }\end{array}$ & \multirow{2}{*}{$\begin{array}{l}\text { Increased heterogeneity, } \\
\text { variability, and dynamics in } \\
\text { work and employment } \\
\text { conditions / HR practices }\end{array}$} & $\begin{array}{l}\text { Employer Authority: } \\
\text { Control over variabilities }\end{array}$ \\
\hline $\begin{array}{l}\text { Employer Acceptance: } \\
\text { Flexibility constraints }\end{array}$ & & $\begin{array}{l}\text { Employee Adaptivity: } \\
\text { Flexibility requirements }\end{array}$ \\
\hline $\begin{array}{l}\text { Need-based: Adjusting } \\
\text { work arrangements to better } \\
\text { fit personal situation, prefer- } \\
\text { ences, and needs of indivi- } \\
\text { dual employees, increasing } \\
\text { wellbeing and performance }\end{array}$ & $\begin{array}{l}\text { Financial: Compensation } \\
\text { Numerical: Work hours } \\
\text { Temporal: Work schedule } \\
\text { Spatial: Work location } \\
\text { Functional: Work tasks }\end{array}$ & $\begin{array}{l}\text { Capacity-based: Adjusting } \\
\text { human resources to better fit } \\
\text { amount, type, and timing of } \\
\text { required labor input, increa- } \\
\text { sing efficiency and respon- } \\
\text { siveness to market dynamics }\end{array}$ \\
\hline $\begin{array}{c}\text { Bottom-up } \\
\text { Employee Initiation }\end{array}$ & $\begin{array}{l}\text { Individual Negotiation: } \\
\text { Idiosyncratic deals }\end{array}$ & $\begin{array}{l}\text { Top-down } \\
\text { Employer Authorization }\end{array}$ \\
\hline $\begin{array}{l}\text { Individually desirable } \\
\text { person-specific variation / } \\
\text { variability in work and } \\
\text { employment conditions }\end{array}$ & $\begin{array}{l}\text { Mutually beneficial, volun- } \\
\text { tary non-standard terms } \\
\text { Temporal: Time-based } \\
\text { Flexibility I-deals } \\
\text { Functional: Task-based } \\
\text { Development I-deals }\end{array}$ & $\begin{array}{l}\text { Representation through } \\
\text { organizational agents acting } \\
\text { in good faith to align } \\
\text { employee-employer interests }\end{array}$ \\
\hline $\begin{array}{c}\text { Theoretical Conception: } \\
\text { Humanization }\end{array}$ & $\begin{array}{l}\text { Dialects of Flexibility: } \\
\text { Ideal- vs. Anti-type I-deals }\end{array}$ & $\begin{array}{l}\text { Practical Adoption: } \\
\text { Rationalization }\end{array}$ \\
\hline $\begin{array}{l}\text { Thesis: I-deals defined / } \\
\text { advocated as positive ideal- } \\
\text { type of individualization } \\
\text { based on ideals of } \\
\text { humanistic management }\end{array}$ & $\begin{array}{l}\text { Synthesis: Subjectification } \\
\text { as negative dialectics } \\
\text { resulting in self-enacted } \\
\text { rationalization / motivated } \\
\text { self-exploitation }\end{array}$ & $\begin{array}{l}\text { Antithesis: Misconstrued / } \\
\text { implemented anti-type of } \\
\text { individualization as labor } \\
\text { political power strategy } \\
\text { based on neoliberal ideology }\end{array}$ \\
\hline
\end{tabular}

\section{CONTENT DIMENSIONS: TEMPORAL AND FUNCTIONAL}

From the organizational perspective, a basic distinction separates internal and external HR flexibility. Whereas former means adapting the workforce through external labor market transactions (hiring and firing), the focus here is on the latter, that is internal processes changing assignment of employees in existing employment relationships, specifically, temporal (timerelated) and functional (task-related) flexibility (e.g., Gouliquer, 2000; Kalleberg, 2003, 2011). However, this does not mean that external (financial and numerical) flexibility is completely irrelevant here, as associated consequences of job and pay insecurity among employees are important to understand the "background pressure" and climate of uncertainty that internal 
flexibility is embedded in (Allan et al., 1999). In theory, there is also an employee side to external flexibility, which refers to the opportunities of workers to choose and change their employers, employment level or income. However, at least under current labor market conditions, it can be assumed that, with the exception of some specialists with highly sought after and rare skills and qualifications, external or labor market flexibility generally tends to result in greater risks and disadvantages for employees than for employers (e.g., Moscone, Tosetti, \& Vittadini, 2016; Pedaci, 2010). This situation relates to the broader pattern of powerdependence imbalance between employees and employers, arising from the fact that, whereas the latter normally have a broad range of options to substitute different types of labor or extend the scope of their hiring efforts, the latter typically rely on employment as a source of income to sustain their livelihood, and thus, their very existence (e.g., Archibald, 2009).

Tensions and trade-offs between organizational and individual interests in workplace flexibility are most commonly studied with regard to temporal aspects, for instance by contrasting capacity-oriented versus autonomy-oriented working time systems or aspects thereof (e.g., Kattenbach, Demerouti, \& Nachreiner, 2010; Lott, 2018). Overall, there is a rich and compelling literature firmly establishing that temporal flexibility is associated with positive outcomes for employees only if (and only to the extent that) the resulting variabilities in the duration, distribution, and scheduling of daily, weekly, and monthly working times are under autonomous control of the respective employees, which, conversely, means limited employer authority over determining the timing of labor input (e.g., Cañibano, 2019; Ropponen, Känsälä, Rantanen, \& Toppinen-Tanner, 2016). In contrast, the capacity-oriented scheduling of work inevitably manifests in time-related stressors and negative implications for employees. What these results allude to, is that in systems of interdependent actors, the flexibility of one party inevitably imposes constraints or restrictions on the other.

With regard to the task-related dimension of functional flexibility employee and employer interest are commonly assumed to be more closely aligned (e.g., Boxall \& Macky, 2014; Daniels, Gedikli, Watson, Semkina, \& Vaughn, 2017). From the organizational perspective, this refers to employing multi-skilled or "polyvalent" human resources, which are able to fulfill a broad range of different tasks, thus generating dynamic capabilities with regard to the scope, quality, and quantity of deliverable products or services. From an employee perspective, functional flexibility can be defined as the ability to exercise influence over what tasks they perform to better align the fulfillment of job duties with their personal and professional preferences, needs, interests, values, or goals. Based on an employee-oriented re- 
conceptualization of flexibility, a humanistic approach towards flexibility that provides workers with increased control over their work goals, methods, and execution can be grounded in established traditions of human-oriented work design, such as action-regulation theory (e.g., Hornung \& Höge, 2019). Nonetheless, although there appears to be an overlap between employee and employer interests in the task domain of flexibility, the central tension of who has the authority to decides what tasks to perform and when, remains an unresolved and contentious issue. The dialectics of flexibility between humanization and rationalization, thus, may be more or less obvious, pertinent, and pronounced for some forms of flexibility than for others, however, associated trade-offs and conflicts are unlikely to completely disappear, regardless of the content dimension.

\section{PROCESS DIMENSIONS: TOP-DOWN AND BOTTOM-UP}

In addition to the content-dimensions, flexibility can be conceptualized in terms of the top-down and bottom-up processes whereby variabilities in organizational practices are created (Hornung, Glaser, \& Rousseau, 2018; Parker, Van den Broeck, \& Holman, 2017; see Table 1). Organizational HR practices, policies, and programs allowing or promoting individual variabilities in work and employment conditions are normally initiated, designed and implemented in a "top-down" fashion by the employer, respectively management. Examples of HR practices introducing variability in job features are part-time work, working time accounts, development or training budgets, self-organizing teams, individual goal setting, and cafeteria benefit plans. Traditionally, research on organizational and work design has focused on such broad-based top-down planned and implemented interventions, for instance, with regard to job enrichment or family-friendly work arrangements (e.g., Daniels et al., 2017; Knijn \& Smit, 2009; Ropponen et al., 2016). The focus of more recent research interest are workplace changes that are initiated and enacted "bottom-up" by employees through discretionary proactive (and deviant) behavior (e.g., Grant \& Ashford, 2008; Parker et al., 2017). Here, person-specific variability results from individual interpretations and use, arguably to the point of "stretching", overreaching or "sidestepping", the formal or "intended" zone of autonomy and discretion associated with the respective job. For instance, this can refer to differences in the way job duties are performed, including which tasks are actually pursued or prioritized, varying degrees of compliance with organizational rules and regulations, individual use of working time arrangements, or personal involvement in training and learning activities. Bottom-up processes introducing person-specific variability and flexibility have been widely studied in the literature on proactive organizational behavior, most notably, with the influential construct of job 
crafting-defined as the modifications employees make to change the task, relational and cognitive boundaries of their work (Rudolph, Katz, Lavigne, \& Zacher, 2017; Wrzesniewski \& Dutton, 2001). Finally, a third way through which variability in work and employment practices can come about has been identified at the intersection of top-down and bottom-up processes, in the form of personalized agreements between individual employees and representatives of their employers, called i-deals (Bal \& Rousseau, 2016; Rousseau, 2005; see Table 1). Individualized employee-employer negotiations are a hybrid of top-down and bottom-up flexibility processes as they are initiated bottom-up by employees and authorized top-down by organizational agents, thus combining characteristics of formalized and self-enacted individualization. This particular type of hybrid flexibility, the focus of the present article, will be discussed in more detail next.

\section{NEGOTIATED FLEXIBILITY: IDIOSYNCRATIC DEALS}

The construct of idiosyncratic deals, or i-deals, was developed by Rousseau (2005) to capture voluntary personalized agreements negotiated between individual workers and employer agents, typically direct supervisors, HR representatives or higher-level managers, who possess the authority to legitimate the respective non-standard terms, such as customized work schedules, job tasks, learning opportunities or career support (e.g., Bal \& Rousseau, 2016; Caliskan \& Torun, 2019; Hornung, Glaser, \& Rousseau, 2018). Assuming that these organizational agents act in good faith on behalf of the employer, i-deals are explicitly defined as authorized and functional arrangements, based on procedural justice, created at the intersection of top-down HR management and bottom-up proactive behavior, and embedded in broader paradigm shifts in organizational theory from classic industrial administration, human relations and sociotechnical systems, to flexible structures and practices. As such, i-deals are theoretically distinct from dysfunctional forms of favoritism and preferential treatment as well as from unauthorized modifications employees implement autonomously to improve their job designs and work experiences, which are most prominently captured in the proactive behavior construct of job crafting (Wrzesniewski \& Dutton, 2001). Specifically, i-deals have been advocated as an instrument to create "win-win" situations, increasing the flexibility of organizations to adapt to change, as well as their ability to attract, retain, and motivate highperformance workforces by aligning jobs with personal needs, preferences and goals.

Based on a critical review of the literature and cumulative own research, Hornung, Glaser, and Rousseau (2018) have provided an integration and evaluation of empirical studies on antecedents and outcomes of mainly two types of i-deals: a) development $i$-deals customizing learning, professional advancement, or career opportunities; and b) flexibility i-deals on the 
distribution and/or duration of work hours. In particular, this contribution has started to call attention to and explore tensions, trade-offs, and externalities arising from i-deals at the individual, interpersonal, organizational, and societal level. Overall, the reviewed studies suggest predominantly positive implications of i-deals - at least at an individual level. Whereas development i-deals tend to increase learning, intrinsic work motivation, affective organizational commitment, and work engagement, flexibility i-deals appear to allow balancing work and private or family demands, reducing time-based stressors and strain (Liao, Wayne, \& Rousseau, 2016). However, results suggest that negative unintended side-effects may occur not only on the individual level, but especially on the group, unit, and societal levels (Hornung, Glaser, \& Rousseau, 2018). This ambivalent role is likely to become particularly pertinent in the context of labor market trends of the neoliberal "rollback" of employee rights and employer responsibilities in post-industrial societies, evident in the erosion of labor laws and collective bargaining, cutting benefits, layoffs, job insecurity, work intensification, and the proliferation of precarious forms of employment (e.g, Allan et al., 1999; Larner, 2000; Rousseau, 2006).

Additional analyses and theorizing support the notion of the possible "dark sides" of ideals under real-world conditions of imbalanced power-dependence relations, concluding that, while in theory functional and fair i-deals are distinct from employment politics and labor utilization strategies, in practice the boundaries are blurry and in need of closer, more explicit, and critical examination (Bal \& Hornung, 2019). The present article continues, extends, and elaborates this undertaking. It contrasts the potentials of i-deals as an employee-oriented management practice, based on unequal but fair treatment according to individual needs and life situations, with concerns regarding use as a labor political rationalization strategy, eroding collective bargaining regulations and aggravating inequalities in status and power through the case-by-case upgrading of "no frills" work contracts stripped of conventional employee benefits. These two antagonistic types of personalized work arrangements are discussed below, after introducing the concept of neoliberal ideology as an overarching contextual framework of organizational flexibility.

\section{THE NEOLIBERAL ORGANIZATIONAL ERA}

There appears to be a wide consensus that the institutions of work and employment in postindustrial societies have entered a qualitatively new and distinctive phase, commonly described as the "neoliberal" organizational era (e.g., Harvey, 2005; Plehwe, Walpen, \& Neunhöffer, 2007; Larner, 2000). Albeit vaguely defined and in itself not uncontroversial (Dunn, 2016), the concept of neoliberalism has been established as a useful label for the 
dominant political-economic doctrine of money and markets, prioritizing economic interests over human welfare (Wacquant, 2009). In more polemic terms, neoliberal ideology promotes "market radicalism", putting "profit over people" in all areas of society (LaMothe, 2016). Against this backdrop, a controversial debate on neoliberal ideology has emerged in the field of work and organizational psychology. At the forefront of this controversy, Bal and Dóci (2018) have suggested a multi-level model of the pervasive influences of neoliberal ideology on organizational practices and scholarship. Their model presents a matrix of political (abstract, idealized, or strategic), social (applied, manifested, or operative), and "fantasmatic" (implied, unconscious, or subliminal) logics, infusing workplace practices as well as their academic representation, assessment, and evaluation with higher-order dogmatic principles of individualism, competition, and instrumentality. Differentiating between the domains of organizational practices and scientific research, this model includes a self-reflexive component, challenging researchers to become more sensitive to their own unquestioned ideological assumptions, implied value-judgements, and inadvertently biased or one-sided theorizing. Specifically, the proposed model suggests that researcher need to critically examine the extent to which widely used theories, concepts, and constructs in work and organizational psychology embody, proliferate, and reproduce unexamined narratives of individualism, competition, and instrumentality, interpreted as socially, psychologically, and morally corrosive (i.e., detrimental) forces of the all-pervasive "Zeitgeist" of neoliberalism (Bal \& Dóci, 2018). Impeding unbiased observation, analysis, and evaluation, ideological thinking is also “intellectually" corrosive (e.g., Davies, 2005), manifesting in widely unchallenged contradictions, counterfactual assumptions, adherence to questionable conventions, nonsensical practices and blind spots - issues plaguing both organizational management in practice as well as academic scholarship.

Scholars analyzing the dynamics of socio-political and economic change, however, have argued that, although the associated ideological forces may converge towards hegemony, indoctrination, manipulation, and domination (i.e., "brainwashing and conditioning") are never total, but tend to open up space for dissent and resistance (e.g., Edwards, 2006; Plehwe et al., 2007). In the case of neoliberal ideology, the seeds for an alternative conception of social relationships and human nature can be found in the ideals of radical humanism, for instance, in the sense of Erich Fromm (Durkin, 2014), forming the roots of critical traditions in social philosophy and underlying alternative forms of organizing (e.g., Reedy, King, \& Coupland, 2016). In line with this conjecture, a counter-model of humanistic ideals has been suggested as 
an antipode to the three content dimensions of the matrix-model of neoliberal ideology (Hornung \& Höge, 2019). Based on dialectic notions of possible futures as dystopia or utopia, power and resistance, action and reaction, etc., this model assembles three core concepts of critical organizational scholarship, specifically, individuation, solidarity, and emancipation at work (e.g., Alvesson \& Willmott, 1992; Huault, Perret, \& Spicer, 2014). The development of this counter-model followed pragmatic considerations in the context of raising attention and providing guidance to researchers regarding alternative values pursued in humanistic and critical traditions in organizational scholarship. Arguably, the three proposed dimensions are more eclectic than comprehensive and only broadly antagonistic to neoliberal logics of individualism, competition, and instrumentality-rather than being their exact opposites. Individuation, solidarity, and emancipation are positioned as antagonistic counter-principles of humanistic management to exemplify dialectic tensions with neoliberal dogmas and utilization strategies (e.g., Fischer, 2003; Melé, 2003). This conceptual model is applied as an analytic vehicle to contrast the humanistic ideal type of idiosyncratic deals as an employee-oriented management practice with the ideologically misconstrued anti-type of individualized work arrangements as a labor political power strategy, reproducing neoliberal agendas of divisiveness, deregulation, and rationalization.

\section{DIALECTICS OF I-DEALS: BETWEEN IDEAL AND IDEOLOGY}

As mentioned above, research on i-deals has stressed positive individual-level outcomes of such individually negotiated work arrangements (e.g., Caliskan \& Torun, 2019; Hornung, Glaser, \& Rousseau, 2018; Liao, Wayne, \& Rousseau, 2016). Specifically, task-related development $\mathrm{i}$-deals have been shown to relate to a range of constructs relevant for employee well-being and performance, such as learning, intrinsic motivation, affective organizational commitment, and work engagement. Time-based flexibility i-deals, on the other hand, have been shown to support employees in balancing work and private demands, buffering negative work outcomes, such as role conflicts, overload, stress, and strain. However, some studies also indicate the possible "dark sides" of $i$-deals under real-world conditions of imbalanced powerdependence relations (e.g., $\mathrm{Ng}, 2017$ ). It appears that, while, in theory, functional and fair ideals are distinct from employment politics and labor utilization strategies, in practice, the boundaries are blurry and in need of closer and more critical examination (e.g., Hornung, 2018; Hornung, Glaser, \& Weigl, 2016). Particularly, his ambivalent role becomes pertinent in the context of current labor market trends associated with the neoliberal "rollback" of employee rights and employer responsibilities in postindustrial societies, manifesting in the erosion of 
labor laws and collective bargaining agreements, widespread slashing of employee benefits, large-scale layoffs, work intensification, job insecurity and proliferation of precarious forms of employment, such as underemployment, temporary and agency work (e.g., Archibald, 2009; Moscone et al., 2016; Pedaci, 2010; Rousseau, 2006; Wacquant, 2009). A core proposition of this research is that the "paradox of flexibility" results in an under-researched and downplayed "dual nature" or dialectic of i-deals as both employee-oriented humanistic management practice (e.g., Fischer, 2003; Melé, 2003) and employer-oriented labor political rationalization strategy (e.g., Bromley, 1990; Rinehart, 1986). Tensions between these antipodes are further analyzed and deconstructed by drawing on the antagonistic concepts of self-actualization versus selfreliance, common welfare versus tournament situations, and social transformation versus economic rationalization, as manifestations of the more abstract higher-level neoliberal and humanistic principles introduced above. Table 2 offers an introduction and description of these concepts, which will be taken up and elaborated in more detail in the following sections.

Table 2. Manifestation of Humanistic Ideals and Neoliberal Ideologies in Ideal-Type and Anti-Type I-deals

\section{Ideal-Type I-deals}

Employee-oriented management practice aimed at realizing humanistic ideals of individuation, solidarity, emancipation

Individuation: Self-actualization

Creating working conditions to support individual and collective learning, personality development, and moral consciousness

Solidarity: Common Welfare

Unequal but fair treatment according to individual needs and situation, emphasizing win-win strategies and generative resources

Emancipation: Social Transformation

Overcoming coercive and limiting powerdependence relationships, creating conditions

for optimal psychological development

\section{Anti-Type I-deals}

Labor political rationalization strategy proliferating neoliberal ideologies of individualism, competition, instrumentality

\section{Individualism: Self-reliance}

Responsibility-shift towards individual; erosion of collective pursuit of common interests, relationships and mutual support
Performance-based allocation of scarce, universally valued resources according to logics of zero-sum, winner-take-all game

\section{Instrumentality: Economic Rationalization}

Defining employees in cost-benefit, meansend, input-output categories as "resources" with no inherent value

\subsection{Ideal Type I-deals: Humanistic Management Practices}

As a humanistic management practice, i-deals emphasize human well-being, the quality of work experiences and social relationships, as well as higher-order needs of personal 
development, psychological growth, and self-actualization (e.g., Fischer, 2003; Melé, 2003; Pircher Verdorfer \& Weber, 2016). These core properties can be conceptualized as an idealistic orientation towards realizing humanistic values of individuation, solidarity and emancipation at work (Hornung \& Höge, 2019). In this context, the goal of individuation or self-actualization can be specified as creating working conditions that facilitate individual yet collectively embedded, learning, growth, and personality development (e.g., Glaser, Hornung, Höge, \& Seubert, 2018; Reedy, King, \& Coupland, 2016). Solidarity refers to social cohesion and prioritization of the common welfare rather than narrow self-interests (e.g., Schnell, Höge, \& Weber, 2019; Weber et al., 2009; 2019). With regard to i-deals, solidarity means embracing unequal but fair treatment according to individual needs and abilities, achieved by pursuing win-win strategies, emphasizing procedural justice, and capitalizing on generative rather than scarce resources (e.g., learning and development, rather than monetary incentives; e.g., Hornung, Doenz, \& Glaser, 2016). Finally, the humanistic ideal of emancipation requires that i-deals are oriented towards social transformation, in the sense of overcoming coercive and limiting structures and power-dependence relationships, and are aimed at creating conditions for optimal psychological development at work (e.g., Alvesson \& Willmott, 1992; Huault et al., 2014). Framed in this positive way, i-deals offer the promise of continuing projects related to the humanization of work by providing a vehicle for employee-oriented flexibility, realizing changes in work and employment conditions that correspond with the individual needs, goals and preferences of the respective employees (e.g., Kissler \& Sattel, 1982). This promise of a positive transformation of work organizations can be summed up as the ideal of using flexibility to develop technocratic or "Tayloristic" working structures into personalized work arrangements, offering "custom-tailored job solutions" to all employees. Arguing for the humanistic nature one could also interpret i-deals as a contemporary, (post-)modern and capitalistic variation of the famous dictum by Marx to treat everybody fairly by adopting a philosophy of "each according to his ability, each according to his needs" (Marx \& Engels, 1978; orig. 1875). However, empirical research and theorizing suggests that such a positive role cannot be assumed or taken for granted-especially in light of powerful ideological forces promoting counter-directed tendencies pushing towards economic rationalization instead of humanization of work (Bal \& Rousseau, 2016; Bal \& Hornung, 2019; Rousseau, 2005, 2006). To ensure that i-deals are functional and fair for all involved parties and stakeholders (e.g., employee, employer, coworkers, other employee groups, collective and societal interests) a number of theoretical prerequisites have been discussed (e.g., Hornung, Glaser \& Rousseau, 2018; Rousseau et al. 2006). Importantly, i-deals are intended as "secondary elasticities" to 
support individual adaptation of and amendments to an intentionally designed, socially just, and responsible formalized HR system. This means that i-deals are best used as a supplement to rather than a substitute for collective employee-oriented practices. Second, it has been argued that the distribution of i-deals should be egalitarian rather than elitist - that is, based on equal opportunity to attain special arrangements depending on individual needs rather than extraordinary performance or high status. Thus, I-deals can create a more level playing field, compensating for or offsetting social inequalities, rather than aggravating or reinforcing them. Third, employee-oriented i-deals emphasize and reflect principles of procedural justice, such as transparent, consistent, considered, and unbiased processes, rather than distributive justice, which more narrowly focuses on the outcome of an equitable allocation of resources (e.g., Hornung, 2010; Hornung, Doenz, \& Glaser, 2016). Lastly, i-deals are relational rather than transactional. Thus, they are more suitable for abstract and intangible resources, such as work activities, personal freedom and development, with particular value and special meaning to the negotiating employee (e.g., Rousseau et al., 2006). In contrast, personalized agreements involving concrete and universally valued aspects, such as pay or working hours, are seen as more problematic, as they run the risk of depriving others of those "fixed-pie" resources.

\subsection{Anti-Type I-deals: Managerial Rationalization Strategies}

Misconstrued as a managerial rationalization strategy, the anti-type of i-deals are transactional and emphasize a narrow form of self-interest and economic rationality, corresponding with suggested dimensions of neoliberal ideology_individualism, competition, and instrumentality (Bal \& Dóci, 2018; Hornung \& Höge, 2019). Individualism, in this context, can be equated with an ideology of self-reliance, which is used to justify the erosion of collective pursuits of common interests, meaningful interpersonal relationships, social support, and responsibility for others (e.g., Greene, 2008). These socially corrosive tendencies are complemented by an excessive emphasis on competition among employees - not only on the labor market, but also within the same organization. Misused in this way, individually negotiated work arrangements result in tournament situations, that is, the performance-based allocation of scarce, universally valued resources according the logics of a "zero-sum-winnertake-all" game (e.g., $\mathrm{Ng}, 2017)$. The dimension of instrumentality refers to the "objectification" of employees as tools or "resources" with no inherent value, conceptualized in terms of costbenefit, means-end, or input-output categories, targeted by economic rationalization, that is, strategies to increase organizational effectiveness and efficiency without regard of or at the expense of the work-related experience, wellbeing, and health of the affected individuals (Bal 
$\&$ Hornung, 2019). In the context of these socially corrosive logics, justified concerns arise regarding the risk that i-deals are coopted to serve as a workforce segmentation and differentiation strategy to decrease labor costs, for instance, by cutting broad-based employee benefits and making employees negotiate for the associated inducements individually, on a case-by-case basis, conditional on performance and organizationally desired work-related behaviors and job attitudes. Inevitably, such offensive uses are bound to contribute to polarization and increasing social inequality and stratification, via processes of cumulative advantage and marginalization, upward and downward "spirals" or so-called "Matthew effects" (e.g., Perc, 2014; Rigney, 2010), for instance, between strategically important "valued core employees" and more "dispensable peripheral workers" (e.g., Cappelli \& Neumark, 2004; Kalleberg, 2003; 2011). Such an instrumental and competition-based approach to individualized work arrangements contradicts and distorts the very notion of i-deals as a humanistic management practice increasing employee-oriented flexibility. Counter-indications of how not to misconstrue i-deals reflect the antipodes of the above discussed features of humanistic management practices (cf. Hornung, Doenz, \& Glaser, 2016; Hornung, Glaser, \& Rousseau, 2018). Specifically, this includes refraining from using personalized agreements as a substitute for formal HR policies and processes, rather than as supplements to a socially responsible designed, integrated and strategically aligned HR framework, providing a broad range of standardized employee benefits. Further, practitioners and academics are cautioned not to adopt or advocate an elitist rather than an egalitarian approach to i-deals, in order to prevent cumulative (dis-)advantages and polarization between more or less privileged and marginalized employee groups, in the sense of hierarchical and increasingly socially stratified HR architectures (e.g., Hornung, Glaser, \& Weigl, 2016; Kang, Morris, \& Snell, 2007). Another common mistake would be to neglect principles of procedural justice, such as fair, transparent, and considered processes, in authorizing personalized arrangements. This includes authorizing i-deals according to the bargaining position or contributions of the respective employees, rather than based on the significance of the requested special arrangements for fulfilling important personal needs of the respective employee (e.g., Hornung, Doenz, \& Glaser, 2016). Finally, it would be misrepresentation of $\mathrm{i}$-deals to use personalized arrangements in a transactional way to reallocate universally valued resources relating to the economic basis of employment, such as pay and positions, generating artificial scarcity and competition among employees, and thus undermining processes of social cohesion, development of shared goals, positive relationships and collaboration that reflect socially desirable counter-directed humanistic objectives and values of employee-oriented management practices (e.g., Pircher Verdorfer \& Weber, 2016; 
Schnell et al., 2019). An overview over the discussed prerequisites and contraindications for designing i-deals in accordance with their definition as a positive ideal-type versus their possible implementation as a negative anti-type is provided in Table 3.

Table 3. Prerequisites and Contraindications of Ideal-Type versus Anti-Type I-deals

\begin{tabular}{|c|c|}
\hline Ideal-Type I-deals & Anti-Type I-deals \\
\hline Humanization Goals & Rationalization Goals \\
\hline $\begin{array}{l}\text { Transforming technocratic work structures } \\
\text { into personalized job arrangements }\end{array}$ & $\begin{array}{l}\text { Increasing effectiveness, and efficiency or } \\
\text { improving cost-structure of HR processes }\end{array}$ \\
\hline Supplementing HR System & Substituting HR System \\
\hline $\begin{array}{l}\text { Used for individual adaptations of socially } \\
\text { responsible general HR framework }\end{array}$ & $\begin{array}{l}\text { Used as replacement for formalized } \\
\text { collective HR policies and practices }\end{array}$ \\
\hline Egalitarian Approach & Elitist Approach \\
\hline $\begin{array}{l}\text { Widespread opportunities to obtain special } \\
\text { arrangements independent of status }\end{array}$ & $\begin{array}{l}\text { Preferential treatment of strategically } \\
\text { important or privileged "star" employees }\end{array}$ \\
\hline Need-based Authorization & Contribution-based Authorization \\
\hline $\begin{array}{l}\text { Accommodating individual needs, } \\
\text { preferences, and life situations of employees }\end{array}$ & $\begin{array}{l}\text { Reflecting bargaining power of social status, } \\
\text { labor market position, or job performance }\end{array}$ \\
\hline Procedural Justice & Distributive Justice \\
\hline $\begin{array}{l}\text { Fair, transparent, and ethical processes for } \\
\text { authorizing personalized working conditions }\end{array}$ & $\begin{array}{l}\text { Equitable allocation of rewards relative to } \\
\text { contributions or inputs }\end{array}$ \\
\hline Relational Resources & Transactional Resources \\
\hline $\begin{array}{l}\text { Immaterial and particular resources of } \\
\text { personal meaning and value to the employee }\end{array}$ & $\begin{array}{l}\text { Material and universally valued resources } \\
\text { related to the economic basis of employment }\end{array}$ \\
\hline
\end{tabular}

\subsection{Ideological Deals: Subjectified Organizational Flexibility}

The above discussed features can be used as heuristics to assess and evaluate organizational practices regarding individualized work arrangements according to the extent that these resemble the humanistic aspirations of ideal-type i-deals and/or their neoliberal antitypes. However, between theses theoretical antipodes, less obvious forms of indirect control are exercised through processes of subjectification, that is, psychological internalization and selfimposition of performance criteria and flexibility requirements by employees (Becke, 2017; Höge, 2011). In contrast to the objectification of employees inherent in the instrumental rationality of technocratic management and rationalization practices, subjectification means that employees spontaneously and autonomously, display socially and organizationally desirable attitudes and behaviors, based on habitually and ideologically reinforced flexible 
patterns of "proactive compliance". The underlying processes, whereby agency and autonomy is transferred to the individual in return for efficient self-management and self-starting pursuit of internalized organizational goals have been described as "responsibilization" (Pyysiäinen, Halpin, \& Guilfoyle, 2017), mental colonization (LaMothe, 2016), fantasmatic influence (Bal \& Dóci, 2018), and governmentality (Lemke, 2002). On the more behavioral level of mainstream research, the results of these psychological processes have attained visibility in increasingly established concepts of self-initiated work stressors, self-endangering work behavior, and self-directed work intensification and extensification (e.g., Deci, Dettmers, Krause, \& Berset, 2016; Dettmers, Deci, Baeriswyl, Berset, \& Krause, 2016; Höge \& Hornung, 2015; Laurence, Fried, \& Raub, 2016). On the organizational level of managerial control and compliance systems, a corresponding development can be observed, which, paradoxically, can be characterized as a shift from control through coercion, compensation or commitment to new forms "control through autonomy", combining intrinsically motivating "high-involvement" work practices with work intensification through delegation, management by objectives, selforganization and normative peer pressure (e.g., Alvesson \& Kärreman, 2004; Boxall \& Macky, 2014; Hornung et al., 2016; Kashefi, 2009). This does not mean that those more traditional modes of managerial control have become irrelevant. They are, in varying degrees and configurations, still in effect, but their exercise has been partly outsourced or externalized by the organization, and, in turn, psychologically internalized by employees, who, thus, have turned from "labor", as an antagonistic force to capital, to self-managing (or self-exploiting) human resources. Analyzing this development, Pongratz and Voß (2003) have drawn similar conclusions, coining the term "entreployee", to refer to the observed new form of subjectified "self-entrepreneurial labor power", which predominantly embodies organizational rather than individual interests (Höge, 2011).

Concepts of subjectification and governmentality are tied to elaborate theoretical frameworks, constitutive bodies of literature, and extensive streams of research, beyond the scope of this article (e.g., Becke, 2017; Larner, 2000; Lemke, 2002; for an overview see: Munro, 2012). Instead, drawing on the above suggested tripartite antagonistic taxonomy, three elements are selectively discussed as complementary concepts to identified characteristics of humanistic versus non-humanistic i-deals: self-exploitation, marketing orientation, and psychological governance. The "negative dialectics" of subjectification mean that the promise of selfactualization (individuation), in conjuncture with the responsibility-shift implied by selfreliance (individualism), promotes self-exploitation (e.g., Edwards, Rust, McKinley, \& Moon, 
2003; Greene, 2008; Hornung et al., 2016). Self-exploitation means, over-commitment and unsustainable, self-endangering efforts to achieve external goals, not aligned with real personal interests, beliefs, and values (e.g., profit maximization vs. social and ecological responsibility, operational efficiency vs. positive work experience, financial performance vs. personal wellbeing and health). I-deals providing only a limited set of options all of which reflect and reproduce neoliberal logics can function as vehicles for such a responsibility-shift, which is only superficially in the interest of employees, but predominantly serves employer agendas (e.g., Pyysiäinen et al., 2017). In the context of neoliberal ideology, subjectification specifically implies the internalization of beliefs in market supremacy, where markets assume a quasi-divine (i.e., godlike) role, becoming the ultimate standards for personal decisions and value judgements, including self-worth, social relationships, and overall life conduct (e.g., LaMothe, 2016; Larner, 2000; Harvey, 2005; McKinnon, 2013). This form of "market fetishism", claiming that markets are the most effective, most efficient and fairest way to organize all areas of life and society, can manifest in a personality preformation or "marketing character", which serves to ideologically "reconcile" the contraction between finding oneself pitted against one's peers in perpetual tournament situations (competition), versus humanistic notions of social cohesion and collaboration towards the common good (solidarity). Finally, tensions between the rationalization logic of economic efficiency (instrumentality) and humanistic goals of social transformation (emancipation) are seemingly "resolved"-but, in effect, rather "shortcircuited"-by the internalization and apparently voluntary and proactive fulfillment of attitudinal and behavioral requirements, as symptoms of indirect control through psychological (self-)governance (e.g., Lemke, 2002).

As mentioned above, the assimilation of these concepts is eclectic and exemplary, rather than theoretically fully conclusive or comprehensive. For instance, the notion of an introjected marketing orientation plays a central role in the psychodynamic social character theory by social philosopher Erich Fromm, which-similar to the larger theoretical frameworks of subjectification and governmentality - in its entirety is a too elaborated theory to be dealt here beyond a cursory mention (e.g., Foster, 2017). Arguably, to some extent, the discussed three aspects also correspond with the "entreployee" concept (Pongratz \& Voß, 2003), describing the defining features of subjectified "self-managing" employees in terms of self-control, selfcommercialization, and self-rationalization (Höge, 2011). Further, parallels can be drawn to various theories and concepts of alienation, specifically self-alienation, social alienation, and "false consciousness" or one-dimensionality (Box, 2011; Costas \& Fleming, 2009). Similar to 
theories of subjectification and governmentality, these latter concepts express a form of "metaalienation", whereby individuals are removed from their genuine societal interests and psychological needs, to the point of fully identifying with their instrumental subservient existence as means for ends that are external to and, eventually, detrimental to their personal wellbeing and socio-moral personality development (cf. Hornung, 2010). Despite conceptual and conative differences, very similar conclusions can be drawn from social character theory (e.g., Foster, 2017) and other attempts to critically describe, analyze, explain, and predict the psychological effects of the ideological regimes governing politically and economically developed and "advanced" democratic Western societies (e.g., Glynos, 2011; Lemke, 2002; Munro, 2012), in contrast to previous phases or present variations of capitalism and alternative configurations of (essentially comparable) political-economic systems.

Figure 1 summarizes the suggested theoretical distinctions and structural relationships between the assembled taxonomies in terms of antagonistic conceptual antipodes on different levels of analysis (cf. Bal \& Dóci, 2018). Accordingly, fundamental antagonisms in the form of higher-order value conflicts between neoliberal ideologies of individualism, competition and instrumentality and corresponding humanistic ideals of individuation, solidarity, and emancipation are reappearing on the organizational level as antagonistic managerial practices serving either predominantly rationalization or humanization purposes. On this level, opposing neoliberal ideologies and humanistic ideals manifests in terms of opposing approaches to work and practices emphasizing either self-reliance or self-actualization, defeating others in tournament situations versus a prosocial orientation towards the common good, increasing economic efficiency or striving for positive social transformation (e.g., Rinehart, 1986; Kissler, $\&$ Sattel, 1982). On the individual level, internalized antagonisms reemerge through processes of subjectification as self-exploitation, marketing orientation, and psychological governance. Whereas dialectical synthesis implies a positive higher-order resolution, the term negative dialectics is used to signify that, as a symptom of psychological domination, underlying contradictions are nor resolved but rather arrested, suppressed, and displaced (e.g., Pyysiäinen et al., 2017). Note that these three levels roughly correspond with the distinction between political, social, and fantasmatic logics, suggested by Bal and Dóci (2018), based on the psychoanalytic work of Glynos (2011). Further, the sub-dimensions of all five tripartite conceptual building blocks can be interpreted as resembling relationships of the individual with regard to their own self, towards others, and their broader societal role. 


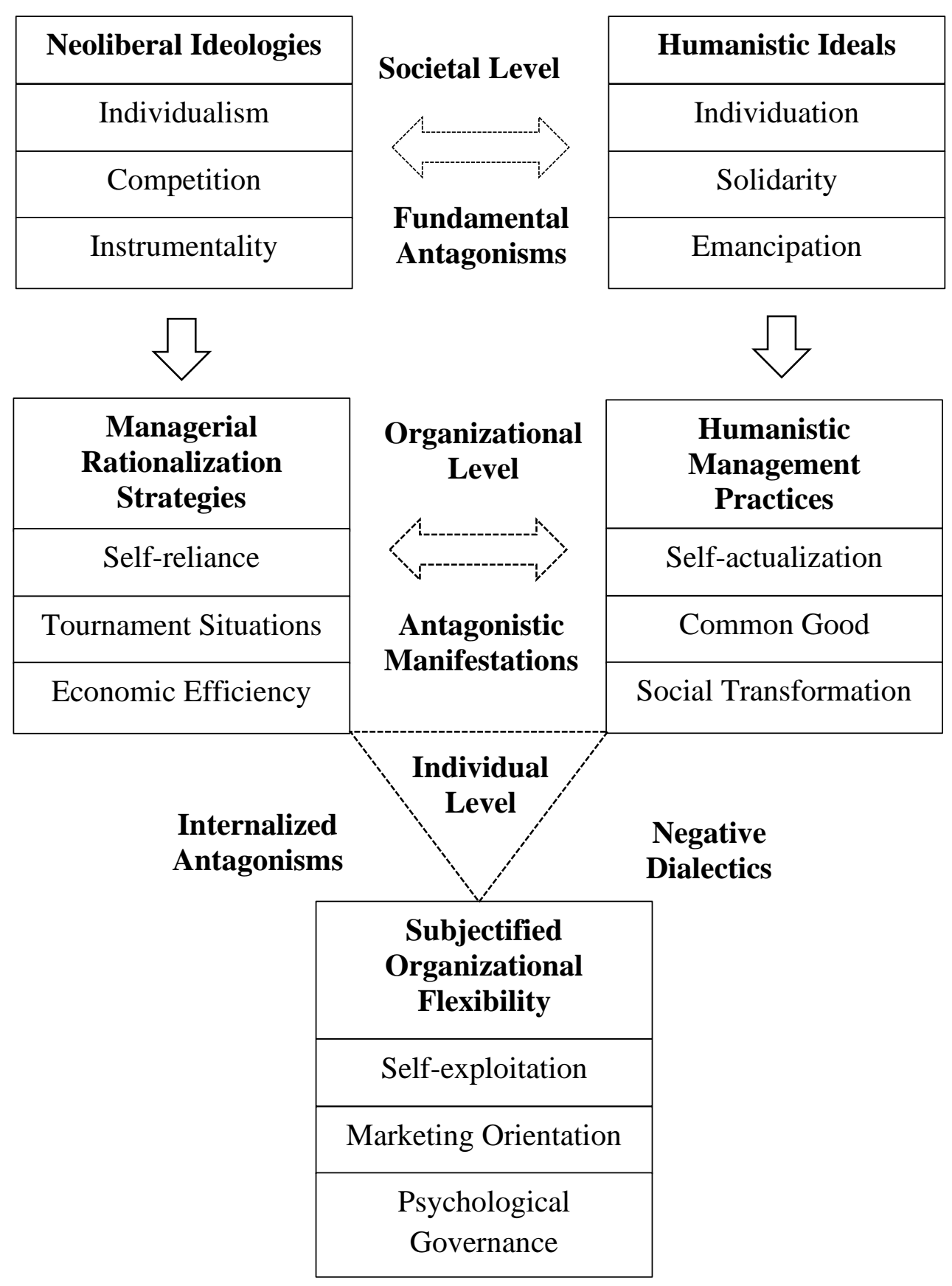

Figure 1. Ideological Antagonisms, Management Approaches, and Subjectification 


\section{CONCLUSION AND OUTLOOK: QUO VADIS?}

Transcending management rhetoric and interest-guided reframing, work and organizational practices need to be more critically assessed and evaluated, especially in the context of neoliberal ideology. Neoliberalism is the globally dominant, largely unchallenged, and increasingly taken for granted political-economic doctrine, which (either explicitly or de facto) prioritizes economic interests of a wealthy social elite over the welfare of the majority of employees and citizens, the environment, and the development of public institutions and civil societies (Harvey, 2005; LaMothe, 2016; Larner, 2000). Associated morally and intellectually corrosive tendencies have been synthesized in a tripartite taxonomy of individualism, competition, and instrumentality. These building blocks of neoliberal ideology have been argued to permeate society, organizations, and individuals through political, social and psychological logics, but also to provoke and activate resistance in the form of counter-directed tendencies of humanistic ideals, such as individuation, solidarity, and emancipation (Bal \& Hornung, 2019; Hornung \& Höge, 2019). The present contribution provides arguments and examples that support the usefulness of the resulting dialectical model by analyzing the concept of employee-oriented flexibility, exemplified by the influential construct of i-deals as individually negotiated work and employment conditions, suggesting characteristics and discussing dynamics of i-deals as humanistic management practices versus neoliberal managerial rationalization strategies.

Conceptualized as an employee-oriented management practice aimed at realizing humanistic ideals of individuation, solidarity, and emancipation, ideal-type i-deals are distinguished from anti-type deals, implemented as a labor political rationalization strategy proliferating neoliberal ideologies of individualism, competition, and instrumentality. Genuinely employee-oriented i-deals thus pursue goals related to the humanization rather than the rationalization of work; supplement rather than substitute socially responsible HR practices, are implemented in an egalitarian rather than in an elitist or meritocratic way, are based on individual needs rather than contributions, on procedural rather than distributive justice, emphasizing relational rather than transactional logics of resource exchange (e.g., Hornung, 2010; 2018). Future conceptual work should continue, elaborate, and extend the presented steps of theory building by integrating additional models, principles, and concepts of critical organizational research. For instance, this refers to systematically applying principles of denaturalization, reflexivity, and anti-performativity with the objective of exposing, deconstructing, and challenging the hidden agendas and interests behind organizational HR 
practices and managerial rhetoric (e.g., Adler, Forbes, \& Willmott, 2007; Fournier \& Grey, 2000). Further, a more comprehensive multi-level approach to studying flexibility and its surrounding discourse is recommended and could possibly be achieved by jointly considering the roles of interests, ideologies, institutions, and identities as well as interactions between these four analytical domains. These conceptual developments should be used to inform and reorient empirical research towards the frequently neglected or downplayed negative side effects and systemic implications of flexibility practices. This includes, for instance, putting stronger emphases on issues of social justice, learning and psychological development, and positive relationships at work, as well as on studying ways to identify, counter, or prevent self-enacted forms of work intensification and extensification. Moreover, such a suggested reorientation of empirical research on flexibility also requires efforts to broaden, adapt, and expand research methods, for example, by integrating quantitative and qualitative, statistical and interpretative, mainstream and critical approaches.

The presented preliminary review and analysis suggests, that, considering the broader interdisciplinary body of literature, at least some steps in the proposed direction of a more critical investigation of contemporary work practices are discernible. In particular, in the field of work and organizational psychology, a new generation of scholars have started to question, challenge, and try to contain or counteract the destructive influences of neoliberal ideology and their implications for organizational practice and academia (Bal et al., 2019). Ironically, growing voices of resistance and critique are likely attributable to the dialectics that the radicalization of capitalism in the neoliberal era continuously reveals and reinforces the conflicts and contradictions that the proponents and protagonists of neoliberalism seek to negate, obscure, or reframe. This interest-guided bias, in turn, requires ever-increasing ideological efforts of political, social, and psychological distortion, distraction, and reframing, which are increasingly hard to reconcile with analytical clarity, intellectual integrity, and academic honesty, let alone the personal and professional responsibility of organizational researchers as social scientists (e.g., Davies, 2005). As Dóci and Bal (2018; p. 559) state "we as researchers need to reflect on how we ourselves are influenced by the very same widespread societal beliefs and ideologies [...]. A plea for workplace dignity as a potential alternative for the dominance of performance as outcome [...] results from the realization that much of our efforts and publications are devoted to a primarily neoliberal agenda." In sum, these authors make a very similar point as Adler and colleagues, who have cautioned that “...prevailing structures of domination produce a systemic corrosion of moral responsibility when any 
concern for people or for the environment requires justification in terms of its contribution to profitable growth" (Adler et al., 2007, p. 121). Following these calls, research on flexibility not only needs to be critical of observed trends in workplace practices, but also constantly needs to be critical of itself, that is, self-reflexive (e.g., Guillemin \& Gillam, 2004), regarding its own role in possibly obscuring, perpetuating, and reproducing — instead of exposing challenging and transforming - socially and psychologically limiting or harmful interests, ideologies, institutions, and identities (e.g., Fournier \& Grey, 2000). It appears that, possibly by taking individualization to the extreme and, thus, being highly in sync with the Zeitgeist, research on idiosyncratic deals seems to be an exemplary, or ideal, case to exercise such a two-pronged critical and self-reflective maneuver (Bal \& Hornung, 2019). Hopefully, the present study can provide some impulses to continue this more critical reorientation of theorizing and research on i-deals and related workplace places facilitating organizational individualization and flexibility. Eventually, such a broader undertaking should be oriented towards developing a more integrated, objective, and self-reflexive meta-theory of the individual, organizational, and societal implications of workplace flexibility and their interactions in forming generalizable patterns in psychological structures und processes, such as values and belief systems, attitudes, thinking habits, affects and emotions, as well as the more deep-seated levels of fantasies, hopes, and imaginations, shaping personal and occupational identities, private and working lives, professional and other social and societal roles (e.g., Bal \& Dóci, 2018; Glynos, 2011; Munro, 2012). In this sense, or, at this point, a comprehensive theory of workplace flexibility converges with a theory of ideology in contemporary societies, organizations, social groups, and individuals. Workplace flexibility, as it turns out, may be best understood from an ideological rather than a behavioral or even a conventional control-oriented perspective. 


\section{REFERENCES}

Adler, P. S., \& Borys, B. (1996). Two types of bureaucracy: Enabling and coercive. Administrative Science Quarterly, 41, 61-89.

Adler, P. S., Forbes, L. C., \& Willmott, H. (2007). Critical management studies. The Academy of Management Annals, 1, 119-179.

Allan, C., O’Donell, M., \& Peetz, D. (1999). Three dimensions of labor utilization: Job broadening, employment insecurity and work intensification. Current Research in Industrial Relations, 1, 13-24.

Alvesson, M., \& Kärreman, D. (2004). Interfaces of control. Technocratic and socio-ideological control in a global management consultancy firm. Accounting, Organizations and Society, 29, 423-444.

Alvesson, M., \& Willmott, H. (1992). On the idea of emancipation in management and organization studies. Academy of Management Review, 17, 432-464.

Archibald, W. P. (2009). Globalization, downsizing and insecurity: Do we need to upgrade Marx's theory of alienation? Critical Sociology, 35, 319-342.

Bal, P. M., \& Dóci, E. (2018). Neoliberal ideology in work and organizational psychology. European Journal of Work and Organizational Psychology, 27, 536-548.

Bal, P. M., Dóci, E., Lub, X., Van Rossenberg, Y. G., Nijs, S., Achnak, S., ... \& De Gieter, S. (2019). Manifesto for the future of work and organizational psychology. European Journal of Work and Organizational Psychology, 28(3), 289-299.

Bal, P. M., \& Hornung, S. (2019). Individualization of work: From psychological contracts to ideological deals. In Y. Griep \& C. L. Cooper (Eds.), Handbook of research on the psychological contract at work (pp. 143163). Edward Elgar, Cheltenham UK

Bal, P. M., \& Rousseau, D. M. (Eds.) (2016). Idiosyncratic deals between employees and organizations: Conceptual issues, applications and the role of co-workers. Routledge, London and New York.

Becke, G. (2017). The subjectivation of work and established-outsider figurations. Historical Social Research / Historische Sozialforschung, 42, 93-113.

Box, R. C. (2011). Marcuse was right: One-dimensional society in the twenty-first century. Administrative Theory \& Praxis, 33, 169-191.

Boxall, P., \& Macky, K. (2014). High-involvement work processes, work intensification and employee well-being. Work, Employment and Society, 28, 963-984.

Bromley, D. W. (1990). The ideology of efficiency: Searching for a theory of policy analysis. Journal of Environmental Economics and Management, 19, 86-107.

Brozovic, D. (2018). Strategic flexibility: A review of the literature. International Journal of Management Reviews, 20, 3-31.

Burchell, B., Ladipo, D., \& Wilkinson, F. (Eds.). (2002). Job insecurity and work intensification. London: Routledge.

Caliskan, E., \& Torun, A. (2019). Individualized HR practices and idiosyncratic deals (i-deals) and the expected positive individual and organizational outcomes. Istanbul Business Research, 48, 36-63

Cañibano, A. (2019). Workplace flexibility as a paradoxical phenomenon: Exploring employee experiences. Human Relations, 72, 444-470.

Cappelli, P., \& Neumark, D. (2004). External churning and internal flexibility: Evidence on the functional flexibility and core-periphery hypotheses. Industrial Relations, 43, 148-182.

Chiva, R. (2014). The common welfare human resource management system: A new proposal based on high consciousness. Personnel Review, 43, 937-956.

Costas, J., \& Fleming, P. (2009). Beyond dis-identification: A discursive approach to self-alienation in contemporary organizations. Human Relations, 62, 353-378.

Davies, B. (2005). The (im)possibility of intellectual work in neoliberal regimes. Discourse: Studies in the Cultural Politics of Education, 26, 1-14. 
Daniels, K., Gedikli, C., Watson, D., Semkina, A., \& Vaughn, O. (2017). Job design, employment practices and well-being: A systematic review of intervention studies. Ergonomics, 60, 1177-1196.

Deci, N., Dettmers, J., Krause, A., \& Berset, M. (2016). Coping in flexible working conditions-Engagement, disengagement and self-endangering strategies. Psychology of Everyday Activity, 9, 49-65.

Dettmers, J., Deci, N., Baeriswyl, S., Berset, M., \& Krause, A. (2016). Self-endangering work behavior. In M. Wiencke, S. Fischer \& M. Cacace (Eds.), Healthy at work-Interdisciplinary perspectives (pp. 37-51). Springer, Cham.

Dóci, E., \& Bal, P. M. (2018). Ideology in work and organizational psychology: The responsibility of the researcher. European Journal of Work and Organizational Psychology, 27, 558-560.

Dunn, B. (2016). Against neoliberalism as a concept. Capital \& Class, 41, 435-454.

Durkin, K. (2014). The radical humanism of Erich Fromm. Critical political theory and radical practice. New York, NY: Palgrave

Edwards, P. (2006). Power and ideology in the workplace: going beyond even the second version of the threedimensional view. Work, Employment and Society, 20, 571-581.

Edwards, J. C., Rust, K. G., McKinley, W., \& Moon, G. (2003). Business ideologies and perceived breach of contract during downsizing: The role of the ideology of employee self-reliance. Journal of Organizational Behavior, 24, 1-23.

Fischer, C. T. (2003). Infusing humanistic perspectives into psychology. Journal of Humanistic Psychology, 43, 93-105.

Foster, R. (2017). Social character: Erich Fromm and the ideological glue of neoliberalism. Critical Horizons, 18, $1-18$.

Fournier, V., \& Grey. C. (2000). At the critical moment: Conditions and prospects for critical management studies. Human Relations, 53, 7-32.

Glaser, J., Hornung, S., Höge, T., \& Seubert, C. (2018). Self-actualization in modern workplaces-time-lagged effects of new job demands and job resources on motivation, meaning and self-efficacy at work. In R.H.M. Goossens (Ed.), Advances in Social \& Occupational Ergonomics. Proceedings of the 8th International Conference on Applied Human Factors and Ergonomics (pp. 253-263). Cham: Springer.

Glynos, J. (2011). On the ideological and political significance of fantasy in the organization of work. Psychoanalysis, Culture \& Society, 16, 373-393

Gouliquer, L. (2000). Pandora's Box: The paradox of flexibility in today's workplace. Current Sociology, 48, 2938.

Grant, A. M., \& Ashford, S. J. (2008). The dynamics of proactivity at work. Research in Organizational Behavior, 28, 3-34.

Greene, T. W. (2008). Three ideologies of individualism: Toward assimilating a theory of individualisms and their consequences. Critical Sociology, 34, 117-137.

Guillemin, M., \& Gillam, L. (2004). Ethics, reflexivity, and “ethically important moments" in research. Qualitative Inquiry, 10, 261-280.

Harvey, D. (2005). A brief history of neoliberalism. Oxford: Oxford University Press

Höge, T. (2011). Perceived flexibility requirements at work and the entreployee-work-orientation: Concept and measurement. Journal Psychologie des Alltagshandelns / Psychology of Everyday Activity, 4 (1), 3-21.

Höge, T., \& Hornung, S. (2015). Perceived flexibility requirements: Exploring mediating mechanisms in positive and negative effects on worker well-being. Economic and Industrial Democracy, 36, 407-430.

Hornung, S. (2010). Alienation matters: Validity and utility of Etzioni's theory of commitment in explaining prosocial organizational behavior. Social Behavior and Personality, 38, 1081-1095.

Hornung, S. (2018). Idiosyncratic deals at work: A conceptual and empirical review. In M. Bilgin, H. Danis, E. Demir \& U. Can (Eds.), Eurasian Business Perspectives. Proceedings of the 20th Eurasia Business and Economics Society Conference Vol. 1. Cham: Springer.

Hornung, S., Doenz, R., \& Glaser, J. (2016). Exploring employee attitudes on fairness of idiosyncratic deals. Organisational Studies and Innovation Review, 2 (4), 9-15. 
Hornung, S., Glaser, J., \& Rousseau, D. M. (2018). Idiosyncratic deals at work: A research summary. Journal Psychologie des Alltagshandelns / Psychology of Everyday Activity, 11 (1), 36-46.

Hornung, S., Glaser, J., \& Weigl, M. (2016). Hierarchical status and job idiosyncrasy in formalized organizations: A field study on hospital physicians. Proceedings 2016 IEEE International Conference on Industrial Engineering and Engineering Management (pp. 316-320). IEEE.

Hornung, S., \& Höge T. (2019). Dialectics of workplace flexibility between humanistic ideal and neoliberal ideology-Preliminary considerations. Journal Psychologie des Alltagshandelns / Psychology of Everyday Activity, 12 (2), 73-83.

Hornung, S., Höge, T., Glaser, J., \& Weigl, M. (2016). Dialectics of high-performance work systems: Disentangling effects of human resource investments and utilization on occupational health. In M. Przygoda, M. Mikic, \& P. Kureci (Eds.), Proceedings 17th International Conference on Economic and Social Development (pp. 300-309). Varazdin, Croatia: VADEA.

Huault, I., Perret, V., \& Spicer, A. (2014). Beyond macro-and micro-emancipation: Rethinking emancipation in organization studies. Organization, 21(1), 22-49.

Kalleberg, A. L. (2003). Flexible firms and labor market segmentation: Effects of workplace restructuring on jobs and workers. Work and Occupations, 39, 154-175.

Kalleberg, A. (2011). Good jobs, bad jobs: The rise of polarized and precarious employment systems in the United States, 1970s-2000s. New York, NY: Russell Sage Foundation.

Kang, S. C., Morris, S. S., \& Snell, S. A. (2007). Relational archetypes, organizational learning, and value creation: Extending the human resource architecture. Academy of Management Review, 32, 236-256.

Kashefi, M. (2009). Job satisfaction and/or job stress: The psychological consequences of working in 'high performance work organizations'. Current Sociology, 57, 809-828.

Kattenbach, R., Demerouti, E., \& Nachreiner, F. (2010). Flexible working times: Effects on employees' exhaustion, work-nonwork conflict and job performance. Career Development International, 15, 279-295.

Kauhanen, M., \& Nätti, J. (2015). Involuntary temporary and part-time work, job quality and well-being at work. Social Indicators Research, 120, 783-799.

Kissler, L., \& Sattel, U. (1982). Humanization of work and social interests: Description and critical assessment of the state-sponsored program of humanization in the Federal Republic of Germany. Economic and Industrial Democracy, 3, 221-261.

Knijn, T., \& Smit, A. (2009). Investing, facilitating, or individualizing the reconciliation of work and family life: Three paradigms and ambivalent policies. Social Politics, 16, 484-518.

Kubicek, B., \& Korunka, C. (2017). Job demands in a changing world of work. Springer, Cham.

LaMothe, R. (2016). The colonizing realities of neoliberal capitalism. Pastoral Psychology, 65, 23-40.

Larner, W. (2000). Neo-liberalism: Policy, ideology, governmentality. Studies in Political Economy, 63, 5-25.

Laurence, G. A., Fried, Y., \& Raub, S. (2016). Evidence for the need to distinguish between self-initiated and organizationally imposed overload in studies of work stress. Work \& Stress, 30, 337-355.

Lemke, T. (2002). Foucault, governmentality, and critique. Rethinking Marxism, 14, 49-64.

Liao, C., Wayne, S. J., \& Rousseau, D. M. (2016). Idiosyncratic deals in contemporary organizations: A qualitative and meta-analytical review. Journal of Organizational Behavior, 37, 9-29.

Lott, Y. (2018). Does flexibility help employees switch off from work? Flexible working-time arrangements and cognitive work-to-home spillover for women and men in Germany. Social Indicators Research, online first publication.

Marx, K., \& Engels, F. (1978). Critique of the Gotha programme. Moscow: Progress Publishers.

McKinnon, A. M. (2013). Ideology and the market metaphor in rational choice theory of religion: A rhetorical critique of 'religious economies'. Critical Sociology, 39, 529-543.

Melé, D. (2003). The challenge of humanistic management. Journal of Business Ethics, 44, 77-88.

Moscone, F., Tosetti, E., \& Vittadini, G. (2016). The impact of precarious employment on mental health: The case of Italy. Social Science \& Medicine, 158, 86-95. 
Munsch, C. L. (2016). Flexible work, flexible penalties: The effect of gender, childcare, and type of request on the flexibility bias. Social Forces, 94, 1567-1591.

Munro, I. (2012). The management of circulations: Biopolitical variations after Foucault. International Journal of Management Reviews, 14, 345-362.

$\mathrm{Ng}$, T. W. (2017). Can idiosyncratic deals promote perceptions of competitive climate, felt ostracism, and turnover? Journal of Vocational Behavior, 99, 118-131.

Osterman, P. (2018). In search of the high road: Meaning and evidence. ILR Review, 71, 3-34.

Parker S. K, Van den Broeck, A., \& Holman, D. (2017). Work design influences: A synthesis of multilevel factors that affect the design of jobs. Academy of Management Annals, 11, 267-308.

Pedaci, M. (2010). The flexibility trap: Temporary jobs and precarity as a disciplinary mechanism. WorkingUSA, $13,245-262$.

Perc, M. (2014). The Matthew effect in empirical data. Journal of The Royal Society Interface, 11, 20140378.

Plehwe, D., Walpen, B. J., \& Neunhöffer, G. (Eds.). (2007). Neoliberal hegemony: A global critique. London: Routledge.

Pircher Verdorfer, A., \& Weber, W. G. (2016). Examining the link between organizational democracy and employees' moral development. Journal of Moral Education, 45, 59-73.

Pongratz, H. J., \& Voß, G. G. (2003). From employee to 'entreployee': Towards a 'self-entrepreneurial' work force? Concepts and Transformation, 8, 239-254.

Putnam, L. L., Myers, K. K., \& Gailliard, B. M. (2014). Examining the tensions in workplace flexibility and exploring options for new directions. Human Relations, 67, 413-440.

Pyysiäinen, J., Halpin, D., \& Guilfoyle, A. (2017). Neoliberal governance and 'responsibilization' of agents: reassessing the mechanisms of responsibility-shift in neoliberal discursive environments. Distinktion: Journal of Social Theory, 18, 215-235.

Reedy, P., King, D., \& Coupland, C. (2016). Organizing for individuation: Alternative organizing, politics and new identities. Organization Studies, 37, 1553-1573.

Rigney, D. (2010). The Matthew effect: How advantage begets further advantage. New York: Columbia University Press.

Rinehart, J. (1986). Improving the quality of working life through job redesign: work humanization or work rationalization? Canadian Review of Sociology / Revue Canadienne de Sociologie, 23, 507-530.

Ropponen, A., Känsälä, M., Rantanen, J., \& Toppinen-Tanner, S. (2016). Organizational initiatives for promoting employee work-life reconciliation over the life course. A systematic review of intervention studies. Nordic Journal of Working Life Studies, 6, 79-100.

Rousseau, D. M. (2006). The shift in risk from employers to workers in the new employment relationship. In E. E. Lawler III, \& J. O'Toole (Eds.), America at work: Choices and challenges (pp. 153-172). New York: Palgrave Macmillan.

Rousseau, D. (2005). I-deals: Idiosyncratic deals employees bargain for themselves. New York: Routledge.

Rousseau, D. M., Ho, V. T., \& Greenberg, J. (2006). I-deals: Idiosyncratic terms in employment relationships. Academy of Management Review, 31, 977-994.

Rudolph, C. W., Katz, I. M., Lavigne, K. N., \& Zacher, H. (2017). Job crafting: A meta-analysis of relationships with individual differences, job characteristics, and work outcomes. Journal of Vocational Behavior, 102, 112-138.

Schnell, T., Höge, T., \& Weber, W. G. (2019). "Belonging” and its relationship to the experience of meaningful work. In R. Yeoman, K. Bailey, A. Madden, \& M. Thompson (Eds.), The Oxford handbook of meaningful work (p. 165-185). Oxford University Press: Oxford (UK).

Smith, W. K., \& Besharov, M. L. (2019). Bowing before dual gods: How structured flexibility sustains organizational hybridity. Administrative Science Quarterly, 64, 1-44.

Volberda, H. W. (1996). Toward the flexible form: How to remain vital in hypercompetitive environments. Organization Science, 7, 359-374. 
Wacquant, L. (2009). Punishing the poor: The neoliberal government of social insecurity. Duke University Press.

Weber, W. G., Unterrainer, C., \& Höge, T. (2019). Psychological research on organisational democracy: A metaanalysis of individual, organisational, and societal outcomes. Applied Psychology, online-first.

Weber, W. G., Unterrainer, C., \& Schmid, B. E. (2009). The influence of organizational democracy on employees' socio-moral climate and prosocial behavioral orientations. Journal of Organizational Behavior, 30, 1127 1149.

Wrzesniewski, A., \& Dutton, J. E. (2001). Crafting a job: Revisioning employees as active crafters of their work. Academy of Management Review, 26, 179-201. 